\title{
The Impact of Electronic Banking on the Credit Risk of Commercial Banks
}

\section{-An Empirical Study Based on KMV Model}

\author{
Zheng Zhao', Yue Lan², Xiaoyu Wu' \\ ${ }^{1}$ School of Economics, Jilin University, Changchun, China \\ ${ }^{2}$ School of Management, Xiamen University, Xiamen, China \\ Email: zhengzhao0527@foxmail.com,80814044@qq.com, 523384857@qq.com
}

How to cite this paper: Zhao, Z., Lan, Y. and Wu, X.Y. (2016) The Impact of Electronic Banking on the Credit Risk of Commercial Banks. Journal of Mathematical Finance, 6, 778-791.

http://dx.doi.org/10.4236/jmf.2016.65054

Received: September 5, 2016

Accepted: November 14, 2016

Published: November 17, 2016

Copyright $\odot 2016$ by authors and Scientific Research Publishing Inc. This work is licensed under the Creative Commons Attribution International License (CC BY 4.0).

http://creativecommons.org/licenses/by/4.0/

\begin{abstract}
Due to the birth of the age of Big Data and the development of Internet finance, electronic banking has been booming. With the application of descriptive statistics, KMV model, panel data regression and robustness testing, this paper examines the validity of KMV model as a measurement of the credit risk of financial institutions, and reveals the impact of electronic banking on the credit risk of commercial banks. The findings are as follows: First, the default distance based on the KMV model can well reflect the credit risk of banks; Second, the growing electronic banking may increase the credit risk, considering the lack of governmental and industrial regulation; At last, the credit risk of banks under different systems have their unique characteristics, so that a clearly defined division of responsibilities for risk control and supervision is needed.
\end{abstract}

\section{Keywords}

Commercial Banks, Electronic Banking, Credit Risk, KMV Model, Default Distance

\section{Introduction}

In recent years, Internet finance has been growing rapidly, and electronic banking has taken a larger share of banking services in commercial banks. In 2014, the users of electronic banking in China amount to 300 million, out of 600 million netizens. Compared with traditional banking, this new form of banking, which is free of the need for counters, not only increases market risks, but also has a great impact on the risk measurement of commercial banks.

The measurement and management of credit risk is one of the most important re- 
search directions in the financial industry. Meanwhile, credit risk is the major risk commercial banks confront, accounting for $60 \%$ of the overall risk. Narrowly speaking, credit risk refers to the risk of debtors failing to make required payments. In 2014, the balance and the ratio of non-performing assets increased dramatically, reaching 30\% and $1 \%-2 \%$ respectively. By the end of 2014, the non-performing loans of commercial banks added up to 842.6 billion yuan, with an increasing number of 250.5 billion yuan in 2014 , compared with 99.2 billion yuan in 2013. Elevated pressure has been put on the adequacy of bank capital due to the surge of non-performing debt and the decline of asset quality.

As a developing country, the credit standing of all levels in China still needs to be improved. Under such environment, it is significant to adopt proper measurement and management of credit risk, so as to manage the capital effectively, preventing the negative influence of the growing Internet finance.

\section{Literature Review}

According to previous studies, the modern measuring models for credit risk underwent a qualitative stage and have entered quantitative stage since 1990. The models mainly include Credit Metrics model, Credit Risk + model, Credit Portfolio View model and KMV model.

Both Credit Metrics model and Credit Portfolio View model rely on credit rating migration matrix, while a thorough credit rating system and long-term practice are required to establish the matrix, which is impractical for China in the short run. Therefore, KMV model is more applicable considering data acquisition and credit rating development.

From the perspective of model applicability, KMV model was first used in IBM and succeeded in predicting its rising default rate before credit deterioration. Subsequently, many western scholars, including J. A. McQuown [1], Jorge R. Sobehart, Sean C. Keenan and Roger M. Stein [2], Kurbat and Korbalev [3] and Korablev and Dwyer [4] have used the data in Asia, Europe and North America to verify the applicability of KMV model in the global financial market. The intermediate output of KMV model, i.e. default distance (DD), default distance produced by KMV model can well explain the credit situation in the above regions. Considering the practice in China, Zhang et al. [5] select fifteen listed companies in 2000 and make use of the default distance to monitor the credit risk of listed companies. The result supported his assumption that KMV is workable to credit risk measurement for companies in Chinese mainland. Later, Ruo-wei Ma [6], Ze-jing Chen et al. [7], Yeh, et al. [8] adopt cases of listed companies to validate the feasibility of KMV model for evaluating companies with different ownership structures, in different industries or with different levels of credit, proving that KMV model is applicable in China.

In China, however, KMV model is mainly used in non-financial institutions. Rarely do researchers apply it to evaluate the credit risk of financial institutions, e.g. commercial banks. The majority of researchers, e.g. Wei, L. U., et al. [9], Lirui Yan [10], Yurong 
Lu and Zijuan Chen [11], select non-financial institutions and compare the default distance derived from the KMV model between ST companies and non-ST companies, verifying the interpretability of KMV model to implicate the credit risk of listed companies. Further inference is drawn that the credit risk of a financial institution will increase if it cooperates with a company whose default distance is relatively short. It can be found that, the studies mentioned above do not directly research into the impact of the intermediate value in the KMV model on the credit risk of commercial banks and are, as a matter of fact, still limited to the risk assessment of non-financial institutions. A few researchers, e.g. Feixue Huang [12], choose commercial banks as samples, and compare the default distance obtained from the KMV model with the credit rating of commercial banks, directly verifying that KMV model can assess credit risks. Nevertheless, it has to be pointed out that credit rating cannot completely reflect credit risks and other factors should also be taken into account. Moreover, the credit rating in China is updated once a year, so that the credit risk represented by the rating may have changed when samples are selected. Based on these factors, there have not been reliable researches on the ability of the intermediate value in KMV model to present the credit risk of commercial banks.

With overall consideration, this paper applies KMV model to investigating the credit risk of listed banks. First of all, the intermediate value derived from the KMV model is substituted into the equation, directly verifying the interpretability of default distance to implicate the credit risk of commercial banks. Then, this paper examines the relationship between the development of electronic banking and the credit risk of banks through an empirical study, and proposes corresponding suggestions for the monitoring system of credit risk, as well as providing references for the department of financial regulations to prevent Internet financial risks and formulate efficient regulations.

\section{Acquisitions of Intermediate Value, Model Construction and Data Selection}

\subsection{Default Distance in KMV Model}

First, the value of the asset and its volatility are estimated. According to the option pricing model, the relationship of the value of asset and the value of equity of a company can be presented by the following function:

$$
V_{E}=V_{A} N\left(d_{1}\right)-D \mathrm{e}^{-r t} N\left(d_{2}\right)
$$

In Equation (3.1.1), $d_{1}, d_{2}, N(d)$ can be presented as follows:

$$
\begin{aligned}
& d_{1}=\frac{\ln \left(V_{A} / D\right)+\left(r+\sigma_{A}^{2} / 2\right) t}{\sigma_{A} \sqrt{t}} \\
& d_{2}=d_{1}-\sigma_{A} \sqrt{t} \\
& N(d)=\int_{-\infty}^{d} \frac{1}{\sqrt{2 \pi}} \mathrm{e}^{-x^{2} / 2} \mathrm{~d} x
\end{aligned}
$$

Differentiate on both sides of Equation (3.1.1): 


$$
\begin{aligned}
& \partial V_{E}=N\left(d_{1}\right) \partial V_{A} \\
& \Rightarrow \partial \ln \left(V_{E}\right)=\frac{V_{A}}{V_{E}} N\left(d_{1}\right) \partial \ln \left(V_{A}\right) \\
& \Rightarrow \sigma_{E}=\frac{V_{A}}{V_{E}} N\left(d_{1}\right) \sigma_{A}
\end{aligned}
$$

In Equation (3.1.2), $V_{E}$ represents the value of equity, $\sigma_{E}$ represents the volatility of the value of equity. Equation (3.1.1) and Equation (3.1.2) can be combined to constitute non-linear equations with unknown parameters, which can be solved iteratively by Newton-Raphson method.

Then, default distance (DD), the distance from the expectation of the value of asset to the default point (DPT), can be calculated. Under the assumption that the value of asset obeys normal distribution, the DD in the KMV model can be shown in the following expression:

$$
\mathrm{DD}=\frac{E\left(V_{A}\right)-\mathrm{DPT}}{E\left(V_{A}\right) \times \sigma_{A}}
$$

As Equation (3.1.3) shows, $E\left(V_{A}\right)$ represents the expected value of asset of a company. $\sigma_{A}$ represents the expected growth rate of the value of asset.

In Equation (3.1.3), the parameters have been determined, while DPT remains unknown. Based on a comprehensive analysis of historical data of default by using KMV model, default point, where default occurs most frequently, is greater than or equal to short-term debt plus $50 \%$ of long-term debt, i.e.:

$$
\mathrm{DPT}=\mathrm{STD}+0.5 \mathrm{LTD}
$$

In Equation (3.1.4), STD refers to short-term debt and LTD refers to long-term debt.

Default distance can be used as a standardized indicator to measure credit risk: the shorter the default distance, the less likely that the company can repay its debt, which indicates a higher risk of default, namely a higher credit risk; on the contrary, the longer the default distance, the more likely that the company can repay its debt, indicating a lower risk of default, namely a lower credit risk.

Considering the purpose of the paper, DD should be calculated for further researches, while the expected default rate (EDF) is not needed in this paper.

\subsection{The Construction of Econometric Models}

Based on the analysis above, this section undertakes a comprehensive analysis, taking seven other influential factors for the rating of credit risks into account. The default distance, which can be obtained from the previous section, is determined as the explained variable. Electronic Banking Transactions (EBT) of commercial banks is determined as a core variable, with non-performing loan ratio (NPR), return on assets (ROA), asset-liability ratio (LEV), loan-deposit ratio (LDR), the stock holding ratio of major shareholders (TOP1) and capital adequacy ratio (CAR) as explanatory variables.

To examine the impact of these factors on default distance, this section makes eco- 
nometric analysis with the application of panal data. The model is as follows:

$$
\mathrm{DD}_{i, t}=c+\beta_{1} \mathrm{EBT}_{i, t}+\beta_{2} \mathrm{NPR}_{i, t}+\beta_{3} \mathrm{ROA}_{i, t}+\beta_{4} \mathrm{LEV}_{i, t}+\varepsilon_{i, t}
$$

In Equation (3.2.1), $i$ denotes individual banks, $t$ denotes year. In the fixed-effect (FE) panal data model, $\mathrm{c}$ is fixed parameter; in the random-effect panal data model, $c$ is random coefficient, is residual; in the mixed-effect (ME) panal data model, $c$ is fixed parameter, is residual. This paper applies F-test, LR test and Hausman test to determining the model adopted.

\subsection{Data Selection and Description}

When calculating the default distance, we obtain the data of 16 banks listed at Shanghai Stock Exchange A share in 2014. Since the Agricultural Bank of China and China Everbright Bank [12] were listed relatively late that their stock price indexes from 2008 to 2010 are unavailable, both of them are eliminated. This paper, therefore, selects 14 banks as research subjects, including 4 state-owned banks, 7 joint-stock banks and 3 urban banks ${ }^{1}$. The recovered closing prices of the 14 sample banks on trading days from January 2, 2008 to December 31, 2014, as well as other indicators, such as total capital at the end of a year (December 31), net assets per share, tradable volume, restricted volume, etc. are acquired from the Wind database.

In the sample time span, Internet finance showed its potential in 2008 and as its main product, the third party payment platforms has come into people's daily lives. In 2010, Yu'e Bao emerged and burgeoned which drived Alibaba, Baidu and Tencent to join the financial industry. In a short time, traditional financial products were replaced by Internet financial products, bringing transition crisis for traditional banks.

By 2014, Internet finance has developed a upgraded industrial structure, covering online payment, online lending and online fund sales. Its game with traditional banks has also received much attention from the governmental regulatory departments. At this crucial moment, how Internet finance may develop in the future becomes a major concern.

Therefore, we selected 2008 to 2014 as our sample period.

For the acquisition of other data, EBT data of commercial banks are obtained from the annual reports of banks ${ }^{2}$ and the data of other indicators are derived from the Wind database (Data Explorer, EDE). The specific criteria for data selection are:

1) According to the previous section, some banks should be eliminated when the time to market is relatively late or information about stock price is incomplete;

2) Considering the development of electronic banking of listed banks, the banks introducing electronic banking relatively late or providing a small scale of electronic banking services should also be excluded from the data;

3) On the basis of the annual report of listed banks, some banks which do not pro${ }^{1}$ The 4 state-owned banks, 7 joint-stock banks and 3 urban banks respectively are: Bank Of Communications, Industrial and Commercial Bank of China, China Construction Bank, Bank of China; Ping An Bank, Shanghai Pudong Development Bank, Hua Xia Bank, Minsheng Bank, Industrial Bank, China CITIC Bank, China Merchants Bank; Bank of Beijing, Bank of Ningbo, Bank of Nanjing.

${ }^{2}$ The EBT can be found in 2008-2014 annual reports of the above 14 banks. 
vide complete information about electronic banking should be eliminated;

4) The banks with abnormal data should be eliminated.

After data selection, 616 annual data of 11 listed banks from 2008 to 2014 are used in the data analysis, excluding the data of Ping An Bank and Bank of Ningbo. We use Eviews 6.0 and the panal data model in econometric analysis.

\section{Empirical Results and Analysis}

\subsection{Descriptive Analysis}

The default distance of different types of commercial banks is calculated and a descriptive analysis is made on the major variables of the model, shown in Table 1 and Table 2 respectively. According to Table 1 and Table 2, the findings are as follows.

Table 1 indicates that systematic differences exist among different banks. The stateowned commercial banks, represented by Bank of Communications, Industrial and Commercial Bank of China, Construction Bank and Bank of China, have a higher level of default distance than the urban commercial banks, represented by Bank of Ningbo, Bank of Nanjing and Bank of Beijing. The urban commercial banks, moreover, have a higher level of default distance than the joint-stock commercial banks represented by Ping An Bank ad Shanghai Pudong Development Bank. These results indicate that banks under different systems have varied standards concerning the management of credit risk. However, whether credit risk is descending successively in state-owned banks, urban commercial banks and joint-stock banks should be further investigated.

Table 1. The average default distance of different commercial banks.

\begin{tabular}{lccccccc}
\hline & 2008 & 2009 & 2010 & 2011 & 2012 & 2013 & 2014 \\
\hline State-owned commercial banks & 1.5694 & 2.9105 & 3.6044 & 4.0283 & 4.9127 & 2.6359 & 2.3065 \\
Urban commercial banks & 1.3712 & 2.3066 & 2.3877 & 2.576 & 2.8080 & 1.4425 & 1.9384 \\
Joint-stock commercial banks & 0.8746 & 2.1285 & 2.4682 & 2.2380 & 2.6980 & 1.1635 & 1.8697 \\
Total & 1.1795 & 2.3901 & 2.7756 & 2.822 & 3.3544 & 1.6440 & 2.0092 \\
\hline
\end{tabular}

Table 2. The descriptive statistics of major variables.

\begin{tabular}{lccccc}
\hline \multicolumn{1}{c}{ Variables } & $\begin{array}{c}\text { Sample } \\
\text { size }\end{array}$ & Mean & $\begin{array}{c}\text { Standard } \\
\text { deviation }\end{array}$ & Min & Max \\
\hline Default distance DD & 77 & 2.392878 & 1.068521 & 0.5085 & 5.4457 \\
Electronic banking transaction EBT & 77 & 70.56266 & 117.0403 & 0.0023 & 631.19 \\
Non-performing loan ratio NPR & 77 & 0.010152 & 0.004229 & 0.0038 & 0.0265 \\
Return on assets ROA & 77 & 1.166708 & 0.204615 & 0.4639 & 1.4748 \\
Asset-liability ratio LEV & 77 & 94.04661 & 1.005373 & 91.8916 & 96.8153 \\
Loan-deposit ration LDR & 77 & 69.70944 & 5.323068 & 56.4 & 83.7836 \\
The stock holding ratio of major shareholders TOP1 & 77 & 32.33314 & 19.46863 & 5.9 & 67.72 \\
Capital adequacy ratio CAR & 74 & 12.23784 & 1.540405 & 9.06 & 19.66 \\
\hline
\end{tabular}


Second, the changes of the default distance for all banks in different years have a strong synergy. Generally, the overall default distance from 2008 to 2012 showed a rising trend, and in 2013 all banks have shown a substantial decline, with a proportion of $50.99 \%$, indicating that the overall credit risk of commercial banks in 2012-2013 surged. We believe that it was due to the accelerated development of shadow banking in the regular banks. On the one hand, short-term deposits are packaged into long-term loans. On the other hand, in this period, commercial banks entrust non-financial institutions with some of their banking services to avoid the scrutiny of regulatory sectors. Such practice reached its peak during 2012-2013. It is estimated in January 2015 that the amount of shadow banking in China had reached 21.6 trillion yuan.

Such practice reached its peak in 2012-2013. It is estimated that in January 2013, the scale of China's shadow banking has reached 20 trillion yuan, equivalent to $1 / 4$ of the total deposits. Although the shadow banking is separated from the banking business of commercial banks, it takes effect concerning risk isolation. Nevertheless, commercial banks will inevitably face a greater moral risk and liquidity strain.

Table 2 indicates that there are systematic changes of default distance, relating to the types of bank and time. In general, however, the default distances remains stable with relatively low volatility. The default distance of commercial banks has a mean of 2.392878, a maximum of 5.4457, a minimum of 0.5085 and a standard deviation of 1.068521. According to the mean, the standard of the sample banks has to decrease by 2.39 times to reach the default point. The results show that the default distance of samples is applicable and there are no extreme cases in the raw data. Moreover, the indicators are appropriate and valid to make statistical analysis.

Table 2 also shows that the electronic banking transaction (EBT) of commercial banks differentiates among individual banks. EBT has a mean of 70.45266 trillion, a maximum of 631.19 trillion, a minimum of 0.0023 trillion and a standard deviation of 117.0403. In the sample banks, the largest electronic banking transaction is more than 20 times the minimum, indicating that different banks are in various stages of development of electronic banking. Some banks already have a complete operational procedures, functional architecture and user groups, but some banks are still at early ages of electronic banking whose scale is rather small. But considering the national conditions of China and the difference of the division of banking services, the huge difference of scales can be expected.

The remaining indicators are also stable in terms of mean, standard deviation and extreme values. They are in the domain of reasonable values, and can be used in the following statistical analysis.

\subsection{Regression Analysis}

Since the data adopted are annual data from 2008 to 2014, unit root tests, including TheiCommom root, Levin, lin \& chu, Individual root, Im, Pesaran and Shin W-stat, Individual root, ADF-Fisher Chi-square and Individual root-PP-Fisher, are conducted before regression analysis to ensure stationarity. The test results are shown in Table 3. 
As shown in Table 3, default distance (DD), Electronic banking transactions (EBT), non-performing loan ratio (NPR), return on assets (ROA), liability of enterprise value (LEV), loan-deposit ratio (LDR), the stock holding ratio of major shareholders (TOP1) and capital adequacy ratio (CAR) are statistically significant at the $1 \%$ level in at least one of the tests.

Considering that random-effects model (RE), fixed-effects model (FE) and mixedeffects model (NE) can all be used in panel data regression, F-test, LR test and Hausman test are carried out to determine the exact model.

F-test and LR test are conducted to decide whether to choose fixed-effects model (FE) or mixed-effects model (NE). The test results are shown in Table 4.

The results show that the probabilities in F-test and LR test are 0.0013 and 0.0084 respectively, both of which are smaller than 0.1 . Thus, the hypothesis that mixed-effects regression is better than fixed-effect regression should be rejected, i.e. Fixed-effect model should be built.

Then, Hausman test is conducted to decide whether to use random-effects model (RE) or fixed-effects model (FE). The test results are shown in Table 5.

Table 3. The results of unit root testing.

\begin{tabular}{|c|c|c|c|c|c|}
\hline & $\begin{array}{c}\text { Levin, } \\
\text { Lin \& Chu t* }\end{array}$ & $\begin{array}{l}\text { Im, Pesaran and } \\
\text { Shin W-stat }\end{array}$ & $\begin{array}{l}\text { ADF-Fisher } \\
\text { Chi-square }\end{array}$ & $\begin{array}{l}\text { PP-Fisher } \\
\text { Chi-square }\end{array}$ & \\
\hline $\mathrm{DD}$ & $\begin{array}{c}-7.57128 \\
(0.0000)\end{array}$ & $\begin{array}{c}-2.43380 \\
(0.0075)\end{array}$ & $\begin{array}{l}45.2371 \\
(0.0025)\end{array}$ & $\begin{array}{l}51.2509 \\
(0.0004)\end{array}$ & stationary \\
\hline EBT & $\begin{array}{c}-2.68087 \\
(0.0963)\end{array}$ & $\begin{array}{l}3.46953 \\
(0.9997)\end{array}$ & $\begin{array}{l}28.3329 \\
(0.0861)\end{array}$ & $\begin{array}{l}32.0415 \\
(0.0067)\end{array}$ & stationary \\
\hline NPR & $\begin{array}{c}-8.87730 \\
(0.0000)\end{array}$ & $\begin{array}{c}-0.33641 \\
(0.3683)\end{array}$ & $\begin{array}{l}29.1829 \\
(0.0397)\end{array}$ & $\begin{array}{l}70.2809 \\
(0.0000)\end{array}$ & stationary \\
\hline ROA & $\begin{array}{c}-13.6601 \\
(0.0000)\end{array}$ & $\begin{array}{c}-8.29982 \\
(0.0000)\end{array}$ & $\begin{array}{l}94.5663 \\
(0.0000)\end{array}$ & $\begin{array}{l}60.0029 \\
(0.0000)\end{array}$ & stationary \\
\hline LEV & $\begin{array}{c}-2.97085 \\
(0.0985)\end{array}$ & $\begin{array}{l}2.13420 \\
(0.9836)\end{array}$ & $\begin{array}{l}24.0144 \\
(0.3465)\end{array}$ & $\begin{array}{l}43.7556 \\
(0.0038)\end{array}$ & stationary \\
\hline LDR & $\begin{array}{c}-2.1 .27263 \\
(0.0000)\end{array}$ & $\begin{array}{c}-1.68263 \\
(0.0462)\end{array}$ & $\begin{array}{l}42.7552 \\
(0.0051)\end{array}$ & $\begin{array}{l}43.6046 \\
(0.0040)\end{array}$ & stationary \\
\hline TOP1 & $\begin{array}{c}-7.07001 \\
(0.0000)\end{array}$ & $\begin{array}{c}-13.2912 \\
(0.0000)\end{array}$ & $\begin{array}{l}93.8512 \\
(0.0000)\end{array}$ & $\begin{array}{l}52.2781 \\
(0.0001)\end{array}$ & stationary \\
\hline CAR & $\begin{array}{c}-6.52819 \\
(0.0000)\end{array}$ & $\begin{array}{c}-0.52791 \\
(0.2988)\end{array}$ & $\begin{array}{l}29.6745 \\
(0.0266)\end{array}$ & $\begin{array}{l}43.2869 \\
(0.0043)\end{array}$ & stationary \\
\hline
\end{tabular}

Table 4. Results of F-test and LR test.

\begin{tabular}{cccc}
\hline Effects Test & Statistic & d.f. & Prob. \\
\hline Cross-section F & 7.845056 & $(10,56)$ & 0.0013 \\
Cross-section Chi-square & 64.812519 & 10 & 0.0084 \\
\hline
\end{tabular}


According to Table 5, the statistic of Hausman test is 63.174384 and p-value is 0.0001. Thus, the hypothesis that random-effects regression is better than fixed-effect regression should be rejected, i.e. Fixed-effect model should be built.

A panal data regression is conducted based on Equation (3.2.1) and the fixed-effects panal data model. The results of the regression are shown in Table 6.

According to Table 6, the relationship of default distance and other influential factors can be concluded as follows:

1) The default distance of a commercial bank has significant negative correlation with its electronic banking transaction. As a result, with the development of electronic banking and the increase of electronic banking transaction, the default distance decreases and the credit risk increases. This may be due to the lack of supervision on electronic banking that banks cannot manage the credit risks as they do in traditional banking, causing higher credit risk.

2) The default distance of a commercial bank has significant negative correlation with its non-performing debt ratio, indicating that the commercial bank with a higher non-performing debt ratio has shorter default distance, i.e. higher credit risk.

3) The default distance of a commercial bank has significant positive correlation with its capital adequacy ratio, indicating that the commercial bank with a lower capital adequacy ratio has longer default distance, i.e. lower credit risk.

\subsection{Robust Test}

At last, the robutness of the empirical results is tested by variable substitution method, i.e., using electronic banking account numbers (EBN) as a substitute for the explanatory

Table 5. Results of Hausman test.

\begin{tabular}{cccc}
\hline Test Summary & Chi-Sq. Statistic & Chi-Sq. d.f. & Prob. \\
\hline Cross-section random & 63.174384 & 7 & 0.0001 \\
\hline
\end{tabular}

Table 6. The results of the fixed-effects panal data regression.

\begin{tabular}{ccccc}
\hline Variable & Coefficient & Std. Error & t-Statistic & Prob. \\
\hline C & -4.878338 & 17.76921 & -0.274539 & 0.7847 \\
EBT & -0.003234 & 0.001566 & -2.064679 & 0.0436 \\
NPR & -218.7205 & 25.74126 & -8.496883 & 0.0000 \\
ROA & -1.450242 & 0.807871 & -1.795141 & 0.0780 \\
LEV & 0.112176 & 0.171313 & 0.654801 & 0.5153 \\
LDR & -0.029550 & 0.032208 & -0.917467 & 0.3628 \\
TOP1 & 0.004312 & 0.040549 & 0.106328 & 0.9157 \\
CAR & 0.227556 & 0.105176 & 2.163577 & 0.0348 \\
R-squared & 0.756240 & Mean dependent var & 2.415691 \\
Adjusted R-squared & 0.682242 & S.D. dependent var & 1.080133 \\
\hline
\end{tabular}


variable EBT. Electronic banking account is the carrier of electronic banking transactions and customers, no matter individual or organization, have to open an account before transactions, so that EBN and EBT are similar explanatory variables.

The robust test model is set as follows:

$$
\mathrm{DD}_{i, t}=c+\beta_{1} \mathrm{EBN}_{i, t}+\beta_{2} \mathrm{NPR}_{i, t}+\beta_{3} \mathrm{ROA}_{i, t}+\beta_{4} \mathrm{LEV}_{i, t}+\varepsilon_{i, t}
$$

The results of unit root test based on Equation (4.2.1) are shown in Table 7.

Table 7 shows that the unit root of EBN is significant at the $1 \%$ level in at least one of the tests and the series is stationary.

The results of F-test, LR test and Hausman test based on Equation (4.2.1) are shown in Table 8 and Table 9.

According to the test results in Table 8 and Table 9, Fixed-effect panal data model should be constructed.

A fixed-effects' panal data regression has been conducted based on Equation (4.2.1) to test the robustness of default distance.

Comparing Table 6 with Table 10, both EBT and its substitute variable EBN, have significant negative correlation with default distance (DD). This result indicates that with the development of electronic banking and the increase of electronic banking transaction, the default distance decreases and the credit risk increases correspondingly. In can be attributed to the increase of customers of electronic banking which makes it harder to manage customers and identify the customers with high credit risks.

In Table 6, the default distance of a commercial bank has significant negative correlation with its non-performing debt ratio. The results in Table 10 are in good agreement with Table 6, shows significant negative correlation between NPR and DD.

In Table 6, the default distance of a commercial bank has significant positive correlation with its capital adequacy ratio and the results in Table 10 show a good agreement.

Table 7. The results of unit root test.

\begin{tabular}{ccccc}
\hline & $\begin{array}{c}\text { Levin, } \\
\text { Lin \& Chu t* }\end{array}$ & $\begin{array}{c}\text { Im, Pesaran and } \\
\text { Shin W-stat }\end{array}$ & $\begin{array}{c}\text { ADF-Fisher } \\
\text { Chi-square }\end{array}$ & $\begin{array}{c}\text { PP-Fisher } \\
\text { Chi-square }\end{array}$ \\
\hline \multirow{2}{*}{ EBN } & -2.46185 & 1.91526 & 16.3137 & 26.2430 \\
stationary \\
\hline
\end{tabular}

Table 8. F-test and LR test results.

\begin{tabular}{cccc}
\hline Effects Test & Statistic & d.f. & Prob. \\
\hline Cross-section F & 7.602286 & $(10,56)$ & 0.0000 \\
Cross-section Chi-square & 63.464129 & 10 & 0.0000 \\
\hline
\end{tabular}

Table 9. Hausman test results.

\begin{tabular}{cccc}
\hline Test Summary & Chi-Sq. Statistic & Chi-Sq. d.f. & Prob. \\
\hline Cross-section random & 58.716474 & 7 & 0.0010 \\
\hline
\end{tabular}


Table 10. The results of fixed-effects panal data regression.

\begin{tabular}{ccccc}
\hline Variable & Coefficient & Std. Error & t-Statistic & Prob. \\
\hline C & -11.69320 & 18.25005 & -0.640722 & 0.5243 \\
EBN & $-3.50 \mathrm{E}-05$ & $1.65 \mathrm{E}-05$ & -2.125939 & 0.0379 \\
NPR & -226.7409 & 25.97993 & -8.727542 & 0.0000 \\
ROA & -1.331993 & 0.810457 & -1.643509 & 0.1059 \\
LEV & 0.176193 & 0.172673 & 1.020386 & 0.3119 \\
LDR & -0.023899 & 0.033474 & -0.713965 & 0.4782 \\
TOP1 & -0.002527 & 0.040095 & -0.063017 & 0.9500 \\
CAR & 0.273676 & 0.113012 & 2.421653 & 0.0187 \\
R-squared & 0.757274 & Mean dependent var & 2.415691 \\
Adjusted R-squared & 0.683590 & S.D. dependent var & 1.080133 \\
\hline
\end{tabular}

In summary, the model is robust. Moreover, the scale of electronic banking transactions is positively related to the bank's credit risk and the result is significant under both conditions when we employ EBT or EBN as a variable in the model.

\section{Conclusions}

According to the previous analysis, the paper utilizes the KMV model to work out Default Distance (DD) that represents the credit risk of commercial banks. Then, DD is served as an explanatory variable in the model along with other selected controlled variables. The conclusion is listed as follows.

First, the default distance based on KMV model is a good indicator of the credit risk of banks. It can be concluded form the empirical study that default distance has a significant positive correlation with non-performing debt ratio, while has a significant negative correlation with capital adequacy ratio. The non-performing loan ratio and capital adequacy ratio are the main and the leading indicators to measure the risk of defaults for banks. This directly shows that the default distance based on KMV model can well reflect the default risk of commercial banks in China.

Second, the level of credit risk varies greatly among banks of different organizing structures. Through statistical analysis of the sample data, we find that the state-owned commercial banks, represented by the Bank of China, have lower credit risk. By contrast, they have a larger scale of electronic banking. Besides, the number of customers, trading frequency and trading volume of state-owned commercial banks is much larger than that of other banks. The urban commercial banks, represented by Bank of Ningbo, have moderate credit risk, but a lower level of electronic banking. The joint-stock commercial banks, represented by Ping An Bank, have high credit risk with a medium level of electronic banking.

Third, the development of electronic banking increases credit risk of commercial banks. According to the empirical results, electronic banking transactions of commer- 
cial banks have significant negative correlation with default distance. In addition, the conclusion still holds if EBT is replaced with EBN. This illustrates that the development of electronic banking does put pressure on the credit risk control of commercial banks. There are basically three reasons: First of all, from the perspective of techniques, due to the Internet and mobile techniques adopted in electronic banking, the technique risk and operating risk may add to the total risk of electronic banking which is relatively greater than traditional banking. Secondly, from the perspective of industry, a common standard of technical safety has not been established in various banks, so there are potential information security vulnerabilities. Consequently, network transmission technology, the safety of electronic channels and internal monitoring systems of operating risk are to be enhanced. Furthermore, from the external aspect, the growth of Internet lending promotes micro loans, whose level of credit rating and risk control standards are relatively low. The cost of default for those customers is lower, so as to aggravate the moral hazard faced by commercial banks. The three reasons above may expose banks to more serious credit risk.

\section{Suggestions}

Based on the discussion above, the three conclusions will give us some guide for credit risk measuring practice in real world.

First, technically speaking, the paper shows that the default distance based on the KMV model can well reflect the credit risk of banks. For both financial and non-financial institutes, the result provided by KMV model is reliable. Furthermore, when compared with other risk assessment models, KMV model is more precise and the data this model uses is more available. We believe that KMV model will play an important role in the theory and practice of the credit risk measurement of China's commercial banks in the near future. However, due to the fact that KMV model is based on the stock price, the credit risk of non-listed companies cannot be calculated by this model, which to a large extent weakens the practical value of KMV model. In the recent decades, researchers have improved KMV model and modified it in order to widen its scope of application. There are several directions of improvements. However, the reliability of none of them has been testified.

Second, for the business strategy of commercial banks, the credit risk management skills under new circumstances should be improved. The paper shows that the development of electronic banking is certainly increasing bank's credit risk level, while the further flourishing of electronic banking seems to be an inevitable trend. Thereby, two objectives are set for the bank. First, the risk prevention ability concerning techniques should be bettered. Traditional commercial banks are the developer, pioneer and practitioner of banking services. In terms of techniques and skills, the traditional commercial banks are not as professional as the Internet companies. However, the security of technology directly affects the electronic banking market, and then affects the entire financial market. Traditional commercial banks should employ advanced technologies, such as network key, key management, digital signatures, etc. Meanwhile, the essential 
techniques and information security management should also be improved to guarantee the safety of the financial market with the application of Internet technology. Secondly, the traditional commercial banks should share the Internet financial database. Most commercial banks have their own online platforms, like e-commerce platforms, which provide rich and comprehensive data of users. These data can be used in the governmental regulation, as well as the expansion of banking services. The establishment of a shared Internet financial database can not only improve the credit system in China, but also help supervise the credit of customers thereby reducing the credit risk of banks.

Third, for administration of the government, a regulatory system with various standards and a clear division of responsibilities are needed to ensure the flexibility of banks and the fairness of markets considering the different systems, level of credit risks and development of electronic banking. First, the current development of electronic banking varies among traditional financial institutions. Commercial banks under different systems have their own operating characteristics and risk management systems. In such a complex market environment, a unified and fixed regulation system may result in an inflexible and homogeneous market. Therefore, the government should establish a flexible regulatory system with a unified principle and varied specific rules based on different situations of companies. Second, the financial safety standards of electronic banking should be established as well. The financial security problem of electronic banking has become one of the major threats to financial market stability. The government should set up technical standards for Internet finance based on the market condition of electronic banking, so that financial institutions will implement unified technical standards, gradually achieving coordinated development. In addition, China should support the research and development of Internet security technology, promote the research and application of domestic security technology, and establish Internet financial security system with independent intellectual property right, realizing technological independence soon.

Only through joint efforts from both banks and government will the financial market enjoy a stable, safe and rapid future development.

\section{References}

[1] McQuown, J.A. (1997) The Illuminated Guide to Portfolio Management: The KMV Portfolio Management Process Model, Addresses Ways in which Portfolio Management Can Mitigate Default Risk and at the Same Time Maximize Business Opportunities, and Gazes into the Future. Journal of Lending and Credit Risk Management, 79, 29-43.

[2] Sobehart, J.R., Keenan, S.C. and Stein, R.M. (2000) Benchmarking Quantitative Default Risk Models: A Validation Methodology. Moody's Investors Service, New York.

[3] Kurbat, M. and Korbalev, I. (2002) Methodology for Testing the Level of the EDF Credit Measure. Moody's KMV Technical Report, 020729, 6-9.

[4] Korablev, I. and Dwyer, D. (2007) Power and Level Validation of Moody's KMV EDF Credit Measures in North America, Europe and Asia. Moody's KMV Technical Report, 070930, 17-18.

[5] Zhang, L., Yang, Z.-S. and Chen, S. (2004) An Application of KMV Model in Credit Risk 
Evaluation of Public Companies. Systems Engineering, 11, 84-89.

[6] Ma, R.-W. (2006) Testing KMV on the Financial Distress of Listed Companies in China. Application of Statistics and Management, 5, 593-601.

[7] Chen, Z.-J., Zhang, X.-H. and Wang, F.-Q. (2008) An Empirical Study of the Credit Risk of Listed SMEs in China Based on the KMV Model. Application of Statistics and Management, 1, 164-175.

[8] Yeh, C.-C., Lin, F.Y. and Hsu, C.-Y. (2012) A Hybrid KMV Model, Random Forests and Rough Set Theory Approach for Credit Rating. Knowledge-Based Systems, 33, 166-172. https://doi.org/10.1016/j.knosys.2012.04.004

[9] Wei, L.U., et al. (2003) KMV Model Applied in Corporate Asset Valuation. Policy-Making Reference, 3, 30-33.

[10] Yan, L.-R. (2009) Credit Risk Empirical Research Based on KMV Model. Journal of Shanxi Finance and Economics University, 5, 104-108.

[11] Lu, Y.R. and Chen, Z.J. (2011) Revised KMV Model to Our Listed Companies Analysis of Applicability of Credit Risk Measurement. Research of Finance and Education, 1, 68-73.

[12] Huang, F.X., Sheng, Y. and Li. Z.J. (2010) Evaluation of Default Risk Based on KMV Model for ICBC, CCB and BOC. International Journal of Economics and Finance, 2, 72-80. https://doi.org/10.5539/ijef.v2n1p72

\section{Submit or recommend next manuscript to SCIRP and we will provide best service} for you:

Accepting pre-submission inquiries through Email, Facebook, LinkedIn, Twitter, etc. A wide selection of journals (inclusive of 9 subjects, more than 200 journals)

Providing 24-hour high-quality service

User-friendly online submission system

Fair and swift peer-review system

Efficient typesetting and proofreading procedure

Display of the result of downloads and visits, as well as the number of cited articles

Maximum dissemination of your research work

Submit your manuscript at: http://papersubmission.scirp.org/

Or contact jmf@scirp.org 